\title{
Algal Toxins in Upper Klamath Lake, Oregon: Linking Water Quality to Juvenile Sucker Health
}

\begin{abstract}
As the lead science agency for the Department of Interior, the U.S. Geological Survey is actively involved in resource issues in the Klamath River basin. Activities include research projects on endangered Lost River and shortnose suckers, threatened coho salmon, groundwater resources, seasonal runoff forecasting, water quality in Upper Klamath Lake and the Klamath River, nutrient cycling in wetlands, and assessment of land idling programs to reduce water consumption. Many of these studies are collaborations with various partners including Department of Interior agencies, Indian Tribes, and State agencies.
\end{abstract}

The Lost River sucker (Deltistes luxatus) and shortnose sucker (Chasmistes brevirostris) were listed as endangered by the U.S. Fish and Wildlife Service in 1988. Since then, recruitment into adult populations has been infrequent, with substantial influxes of new spawners coming predominantly from early 1990s year classes. Poor recruitment may be linked to high mortality during juvenile life stages. Sharp declines in catch rates of age- 0 suckers during early fall and extremely low catches of age- 1 suckers suggest low recruitment may be caused by an ecological "bottleneck" occurring between the first and second summers of life.

The largest remaining habitat for these fish is Upper Klamath Lake, a hypereutrophic lake in southern Oregon, where massive blue-green algae (cyanobacteria) blooms occur annually. These blooms, dominated by Aphanizomenon flosaquae, and the subsequent decay of dead algae result in waterquality problems, including $\mathrm{pH}$ of 9.5 and higher, dissolvedoxygen concentrations that fluctuate from supersaturation to near anoxia, and high ammonia concentrations. Degraded water quality has caused occasional major die-offs of adult fish in Upper Klamath Lake and has been proposed as a contributing factor in the overall decline in Lost River and shortnose sucker populations. In addition to producing extremes in water quality, blooms of blue-green algae can produce toxins potentially harmful to fish.

The USGS began preliminary research on the presence, concentration, and dynamics of algal toxins in Upper Klamath Lake in 2007. Microcystin, a hepatotoxin (liver toxin), was

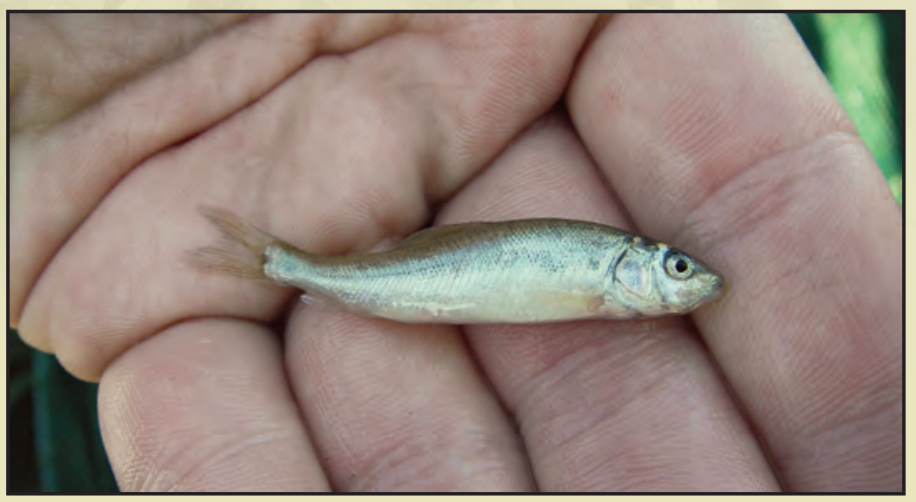

Age-0 sucker captured from Upper Klamath Lake, Oregon.

detected both in samples of the particulate material from the lake and dissolved in lake water. In 2007, water samples were collected once per month at six sites from July to October. At most sites and on most sampling dates, microcystin concentrations were equal to or greater than the World Health Organization (WHO) limit for drinking water (1 $\mu \mathrm{g} / \mathrm{L})$ and peaked at $17 \mu \mathrm{g} / \mathrm{L}$. In 2008, water samples were collected every 2 weeks at five sites from late June through September. Microcystin levels generally were lower than in 2007, but concentrations at some sites were greater than the WHO limit and reached a peak of $6 \mu \mathrm{g} / \mathrm{L}$.

Preliminary studies of the possible effects of algal toxins on juvenile suckers in Upper Klamath Lake also were begun in 2007. From July to September 2007, 47 age-0 suckers were collected from 11 shoreline sites located throughout the lake

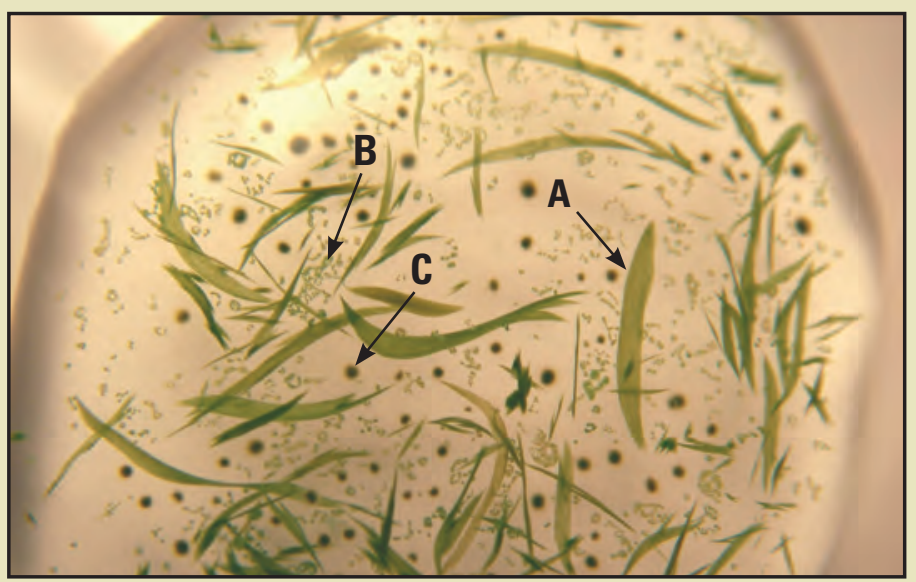

Lake water subsample containing colonies of Aphanizomenon flos-aquae (A), Microcystis (B), and Gloeotrichia (C). Magnification $=3 \times$. Photograph by Sara Eldridge, U.S. Geological Survey. 
and examined for histopathology. Pathology consistent with microcystin exposure was found in 49 percent of these fish. Individuals captured in the northern region of the lake exhibited an elevated percent occurrence of multiple organ necrosis relative to those collected in the southern region. From July to September 2008, 103 age-0 suckers were collected from five geographic areas encompassing the lake and were examined for histopathology. Evidence of organ damage was absent from fish collected in two areas and present in less than 20 percent of those from all other areas. Similar to 2007, the area with the highest prevalence of pathology was in the north. The cause and significance of regional differences are unclear, as it could have resulted from differences in the postulated algal toxin exposure including dose, duration of exposure, and time since exposure.

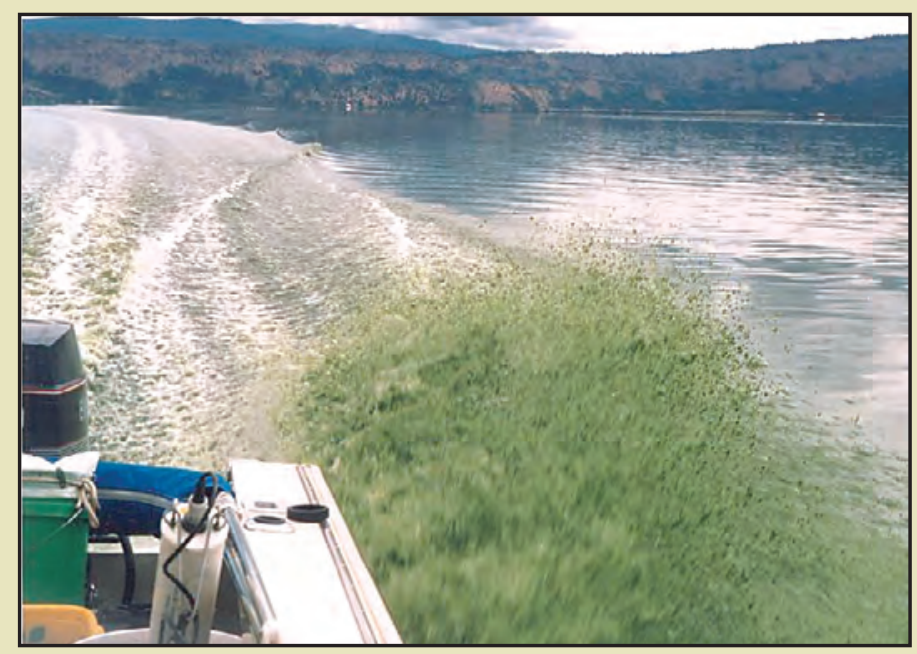

Algal bloom conditions in Upper Klamath Lake, Oregon.

Evidence of the route of exposure to algal toxins was provided by a gut analysis of 45 fish collected during summer 2008. The gut analysis showed that the juvenile suckers had ingested chironomid larvae, and that these chironomid larvae in turn had filaments of $A$. flos-aquae and colonies of Microcystis aeruginosa, a known cyanotoxin producer, in their digestive tracts. Because the juveniles examined had all completed the ontogenetic shift to a diet based on benthic feeding, these chironomids would have come from the bottom sediments. Furthermore, the histology of the fish showed numerous gastrointestinal lesions. These lesions were observed when liver necrosis was either present or absent suggesting that the gastrointestinal tract was the first point of toxin contact. Although the existing data do not rule out other lesion etiologies, they are consistent with hepatotoxin exposure. The observed histopathology did not indicate a bacterial or parasitic etiology, but an etiology involving an undetected virus could not be dismissed with certainty. The most obvious cause of lesions, however, typically is the etiology of concern. Thus, the totality of the evidence indicates that the fish were exposed to algal toxins, and that the route of exposure to toxins was an oral route through the food chain, rather than exposure to dissolved toxins at the gills.

Suggested citation: VanderKooi, S.P., Burdick, S.M., Echols, K.R., Ottinger, C.A., Rosen, B.H., and Wood, T.M., 2010, Algal toxins in upper Klamath Lake, Oregon: Linking water quality to juvenile sucker health: U.S. Geological Survey Fact Sheet 2009-3111, $2 \mathrm{p}$.

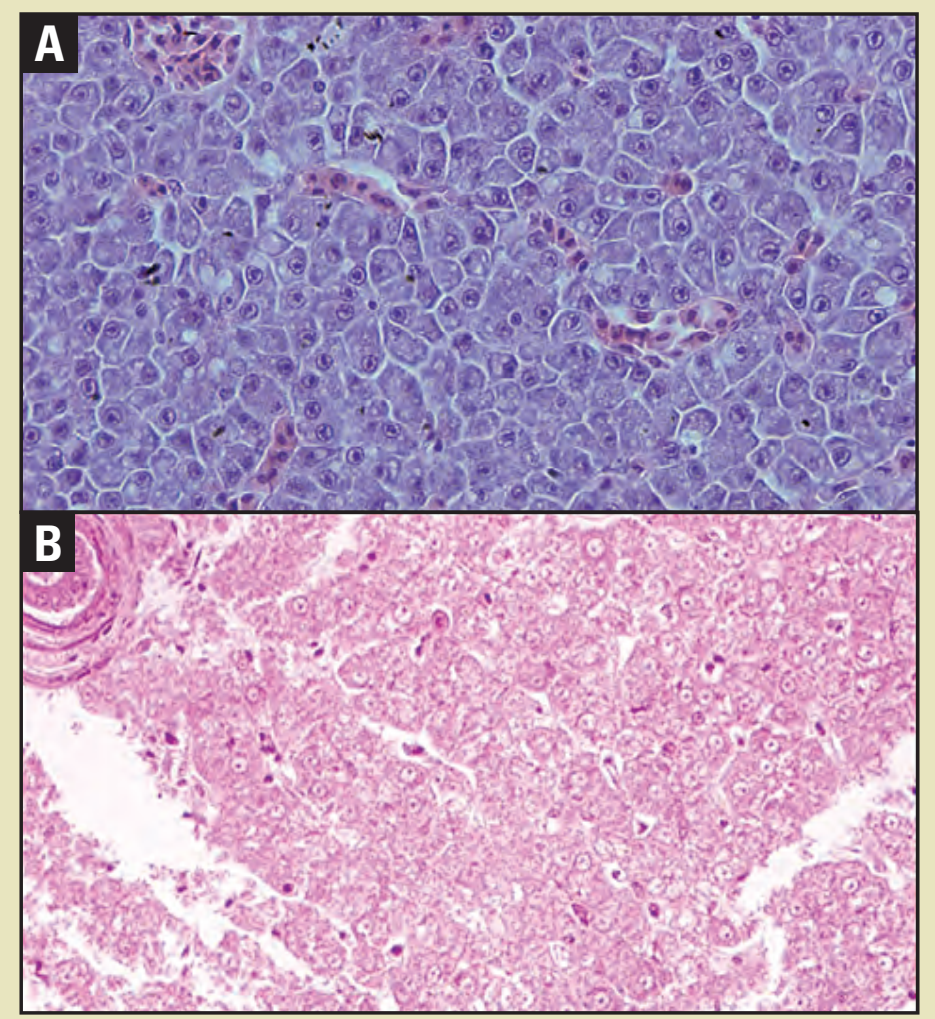

Normal liver tissue (A) from an adult Upper Klamath Lake sucker obtained in April 2006 and tissue exhibit hepatocellular necrosis as indicated by the lack of well-defined cells (B) from a juvenile sucker collected from Upper Klamath Lake in August 2007.

Magnification $=200 \times$. Hematoxylin and eosin. Photographs by Dr. Christine Densmore, U.S. Geological Survey.

Given our observations in 2007 and 2008, we developed a collaborative, interdisciplinary study design for work beginning in 2009 to better understand the threats algal toxins pose to juvenile Lost River and shortnose suckers. Our objectives are to determine which toxins are present and at what concentrations, as well as what effects these compounds may have on the health and condition of juvenile suckers. An additional objective is to relate the spatial and temporal occurrence of toxins, particularly in near-shore sediments where they overlap with the presence of juvenile suckers, to lake-wide water quality and blue-green algae bloom dynamics.

Clarification of the roles algal toxins have in the survival of young suckers will improve our understanding of key factors thought to be preventing the recovery of these species. This information also may prove useful to resource managers by helping guide decision making and to identify and prioritize restoration needs in the Upper Klamath River basin.

Publishing support provided by the U.S. Geological Survey Publishing Network, Tacoma Publishing Service Center

For more information concerning the research in this fact sheet, contact the Director, USGS Western Fisheries Research Center 6505 NE 65th Street

Seattle, Washington 98115

206-526-6282

http://wfrc.usgs.gov/ 